\title{
Analisis kelayakan usaha tani kubis (Brassica Oleracea L.) di desa Beji Kecamatan Junrejo kota Batu
}

Analysis of the feasibility of farming cabbage (Brassica Oleracea L.) in Beji Village, Junrejo District, Batu City

\author{
Yuhanin Zamrodah ${ }^{1) *}$ \\ ${ }^{1}$ Program Studi Agribisnis Fakultas Pertanian Universitas Islam Balitar, Blitar, Indonesia \\ *Email korespondensi: yuhaninzamrodah@unisbablitar.ac.id
}

Informasi artikel: Dikirim: 30/05/2020 Ditinjau: $30 / 05 / 2020$ Disetujui: 25/09/2020

Copyright (c) 2020 Yuhanin Zamrodah
ABSTRACT: The aim of this studies were to determine the efficiency or feasibility of cabbage farming income, income earned by farmers in one growing season. Research locations in Beji Village, Junrejo Subdistrict, the number of respondents were 30 cabbage farmers which were used as research samples. The data used primary data and secondary data. Method of analysis, namely the analysis of income $P d=T R-T C$, analysis of costs $T C=F C+V C$, analysis of acceptance $T R=$ $P y . Y$ and analysis of the feasibility of $R / C$ farming. The results obtained with a total revenue of $R p .53,473,500.00$; the variable cost is IDR 11,807,025.00; flat fee of IDR. 3,010,000.00; total cost of IDR. 14,817,025.00; the average income earned by cabbage farmers is IDR. 14,817,025.00; and obtained $R / C$ value of 2.61 which means that each expenditure of IDR. 100.- will receive IDR. 261.00. Thus the cabbage farming in Beji Village is feasible to be cultivated because $R / C>1$ means that the farming is profitable. Therefore, this farm is worth continuing.

Keyword: cabbage farming, income, efficiency

ABSTRAK: Tujuan dari penelitian ini adalah untuk menentukan efisiensi atau kelayakan pendapatan pertanian kubis, pendapatan yang diperoleh petani dalam satu musim tanam. Lokasi penelitian di Desa Beji, Kecamatan Junrejo, jumlah responden yang digunakan dalam penelitian ini adalah 30 petani kol. Data yang digunakan berasal dari data primer dan data sekunder. Metode analisis, yaitu analisis pendapatan $\mathrm{Pd}=\mathrm{TR}-\mathrm{TC}$, analisis biaya $\mathrm{TC}=\mathrm{FC}+\mathrm{VC}$, analisis penerimaan $\mathrm{TR}$ $=$ Py. $\mathrm{Y}$ dan analisis kelayakan pertanian R/C. Hasil yang diperoleh dengan total pendapatan sebesar Rp. 53.473.500,00; biaya variabel adalah Rp11.807.025,00; biaya tetap Rp. 3,010,000.00; total biaya Rp. 14.817.025,00; penghasilan rata-rata yang diperoleh petani kubis adalah Rp. 14.817.025,00; dan diperoleh nilai $\mathrm{R} / \mathrm{C}$ sebesar 2,61 yang berarti bahwa setiap pengeluaran sebesar Rp. 100.- akan menerima Rp. 261.00. Dengan demikian pertanian kubis di Desa Beji layak untuk dibudidayakan karena $\mathrm{R} / \mathrm{C}>1$ berarti pertanian tersebut menguntungkan. Oleh karena itu pertanian ini layak untuk dilanjutkan.

Kata kunci: pertanian kubis, pendapatan, efisiensi

Sitasi: Zamrodah, Y. (2020). Analisis kelayakan usaha tani kubis (Brassica Oleracea L.) di desa Beji Kecamatan Junrejo kota Batu. AGROMIX, 11(2), 241-249. https://doi.org/10.35891/agx.v11i2.2061

\section{PENDAHULUAN}

Bidang pertanian merupakan sektor

terpenting bagi kelangsungan hidup penduduk

di Indonesia, karena sektor pertanian sebagai

penopang kehidupan sebagian besar

masyarakat di Indonesia, dengan demikian sektor pertanian di Indonesia perlu terus ditingkatkan seiring dengan kemajuan teknologi dan pertumbuhan penduduk. Pemenuhan konsumsi pangan masyarakat di era pembangunan, produksi berperan penting (Aschemann-Witzel dkk., 2019; Movilla-Pateiro 
dkk., 2020; Nemeth dkk., 2019; Sheng \& Song, 2019). Indonesia juga sangat dikenal sebagai salah satu negara yang banyak memproduksi hasil hortikultura. Tanaman hortikultura terbagi atas beberapa komoditas yaitu tanaman hias, buah-buahan, dan sayuran yang termasuk komoditas penting yang dapat mendukung ketahanan pangan secara nasional, dan memiliki berbagai jenis yang banyak, juga berperan sebagai sumber vitamin dan mineral yang memiliki nilai ekonomis. Sayuran sebagai salah satu komoditas hortikultura yang berkembang serta sangat diminati oleh masyarakat adalah kubis.

Sunarjono (2013), menyatakan bahwa kubis adalah tanaman semusim. Bentuk tanaman kubis memiliki batang pendek serta beruas-ruas untuk tempat duduk daun, mudah tumbuh pada ketinggian di atas 750 mdpl dan dataran rendah yang sudah di lakukan penelitian. Brassica oleracea adalah makanan nabati yang ditemukan dalam varietas merah dan putih, dan telah dikonsumsi di seluruh dunia sebagai mentah atau dimasak (Anunciação dkk., 2011). Pada tanah yang masam kubis dapat tumbuh dengan baik, akan

tetapi pada $\mathrm{Ph}$ tanah yang netral kubis juga dapat tumbuh walau hasilnya kurang baik. Kubis termasuk tanaman dua musin, juga ditanam sebagai tanaman semusim (Ashari, 1995). Kubis merupakan sayuran jenis Brassica yang mudah di dapatkan di manapun. Secara biologis, kubis masih berkaitan dengan brokoli, kembang kol, dan sayur kale. Kandungan gizi pada kubis yaitu mengandung vitamin K, C, B6, B1 dan Volat yang penting bagi tubuh (Alamgir, 2018; Patty, 2018; Sun dkk., 2014). Selain itu terdapat karbohidrat, protein, mangan, serat, kalsium, kalium, magnesium, sejumlah mikronutrien seperti vitamin $A$, zat besi, dan riboflavin juga terkandung dalam kubis. Sebanyak 54 \% kebutuhan vitamin C setiap hari dapat dipenuhi dalam $50 \mathrm{gr}$ kol yang sudah di masak. Sayuran ini memiliki kalori rendah dan tidak terdapat lemak. Kandungan vitamin A, B dan $C$ dalam kubis sangat bermanfaat bagi kesehatan tubuh manusia karena termasuk antioksidan alami yang dapat mencegah berbagai penyakit (Cahyono, 2002). Produktivitas kubis di Jawa Timur selama tahun 2013-2017 sebagai berikut:

Tabel 1. Produktivitas tanaman kubis di Jawa Timur

\begin{tabular}{ccc}
\hline No & Tahun & Produktivitas (Ton/Ha) \\
\hline 1 & 2013 & 22,46 \\
2 & 2014 & 25,24 \\
3 & 2015 & 21,50 \\
4 & 2016 & 19,99 \\
5 & 2017 & 23,81 \\
\hline
\end{tabular}

Sumber: Badan Pusat Statistik [BPS] [2018] 
Berdasarkan tabel 1 di atas dapat produktivitas kubis dari tahun sebelumnya diketahui bahwa produktivitas kubis di Jawa sebesar 23,81 ton/ha. Produktivitas kubis dari Timur pada tahun 2013 sebesar 22,46 ton/ha, tahun ke tahun sangatlah fluktuatif, hal ini bisa tahun 2014 meningkat sebesar 25,24 ton/ha, dipengaruhi oleh cuaca, cara bercocok tanam, pada tahun 2015 mengalami penurunan pengolahan lahan dan serangga tanaman produktivitas kubis sebesar 21,50 ton/ha, tahun sehingga mengakibatkan produktivitas kubis 2016 mengalami sedikit penurunan mengalami kenaikan ataupun penurunan. Luas produktivitas kubis sebesar 19,99 ton/ha dan Panen dan Produksi kubis di Kota Batu sebagai pada tahun 2017 mengalami sedikit kenaikan berikut:

Tabel 2. Produksi kubis di kota Batu tahun 2016

\begin{tabular}{ccc}
\hline No & Bulan & Produktivitas (Kw/Ha) \\
\hline 1 & Juli & 6140 \\
2 & Agustus & 6315 \\
3 & September & 6244 \\
4 & Oktober & 7125 \\
5 & November & 5830 \\
6 & Desember & 4725 \\
\hline
\end{tabular}

Sumber: Badan Pusat Statistik [BPS] [2018]

Berdasarkan tabel 2 di atas dapat diketahui produktivitas kubis di kota Batu Jawa timur pada tahun 2016 bulan juli sebesar 6.140 $\mathrm{ha} / \mathrm{kw}$, pada bulan Agustus mengalami peningkatan sebesar $6.315 \mathrm{ha} / \mathrm{kw}$, pada bulan September mengalami sedikit penurunan sebesar $6.244 \mathrm{ha} / \mathrm{kw}$, pada bulan Oktober kembali mengalami kenaikan sebesar 7.125 ha/kw, pada bulan November dan Desember kembali mengalami penurunan berturut-turut sebesar $5.830 \mathrm{ha} / \mathrm{kw}$ dan $4.725 \mathrm{ha} / \mathrm{kw}$. Penurunan produktivitas tanaman kubis dapat disebabkan oleh berbagai hal di antaranya disebabkan oleh faktor cuaca, gangguan serangan hama dan penyakit serta penggunaan pupuk dan cara bercocok tanam.
Cara-cara yang dapat menentukan, mengorganisasikan, dan mengkoordinasi penggunaan faktor secara produksi seefektif, seefisien dengan memberikan pendapatan semaksimal disebut dengan usahatani (Anjayani \& Haryanto, 2009). Usahatani merupakan suatu jenis kegiatan yang mengusahakan serta mengkoordinir beberapa faktor produksi berupa lahan, pekerja, serta income. Sentra produksi sayur terbesar di Jawa Timur terdapat di kota Batu yang paling banyak adalah sayur kubis. Banyak petani yang berusaha tani kubis karena dianggap sangat menguntungkan. Fluktuasi harga kubis tidak menentu berdampak pada pendapatan petani.

Masalah yang sering dihadapi oleh petani kubis di Desa Beji Kota Batu di antaranya 
adalah harga jual yang diterima dari hasil budidaya sayuran kubis sering mengalami fluktuasi. Apabila panen kubis melimpah dan sedang panen raya, maka harga dapat turun begitu pula sebaliknya apabila panen kubis sedikit maka harga bias melambung tinggi, sehingga petani mengalami kerugian. Peningkatan produktivitas sebaiknya diimbangi dengan harga jual yang sesuai. Efisiensi produksi dan produktivitas usahatani dalam peningkatan pendapatan dan kesejahteraan petani pada tingkat perdesaan merupakan syarat utama (Fitriani, 2012). Selain itu faktor alam juga ikut mempengaruhi produksi petani, cuaca yang tidak menentu menjadi masalah yang menyebabkan kegagalan usahatani ini. Berbagai upaya dengan proses pengolahan yang baik dan benar sehingga kerugian dapat dihindari. Analisis usahatani dibutuhkan sebagai pemeriksa terpakainya sarana dan prasarana sehingga akan diketahui sampai seberapa jauh tingkat keberhasilan dalam usahataninya.

Dari uraian di atas maka, penting penelitian ini dilakukan untuk mendapatkan gambaran usahatani sayuran kubis diperlukan adanya analisis ekonomi yang mencakup analisis biaya produksi, analisis biaya dan pendapatan, serta analisis kelayakan usahatani.

\section{METODE}

Desa Beji Kecamatan Junrejo sebagai lokasi penelitian, dilaksanakan pada bulan
Februari - Maret tahun 2020. Penentuan responden dalam penelitian ini dilakukan Simple Random Sampling method, di mana unsur dalam semua populasi memiliki kemungkinan yang sama untuk menjadi sampel peneliti (Malinga dkk., 2015; Sudrajat, 2005). Jumlah responden dalam penelitian adalah 30 KK petani kubis. Data yang digunakan dalam penelitian ini bersumber dari data primer dan data sekunder. Metode analisa data menggunakan analisis biaya dengan menghitung besarnya biaya total dengan cara menjumlahkan biaya tetap dengan biaya variabel atau TC : FC + VC (Suratiyah, 2009), analisis Penerimaan dengan menghitung penerimaan total dengan menggunakan perkalian antara jumlah produksi dengan harga jual atau TR : Py . Y, analisis Pendapatan dengan menghitung selisih antara penerimaan dan biaya total atau Pd: TR - TC (Soekartawi, 2007), analisis $\mathrm{R} / \mathrm{C}$ merupakan perbandingan antara penerimaan dengan biaya total (Faizal, 2009).

\section{HASIL DAN PEMBAHASAN}

\section{Identitas responden}

Responden yang digunakan sebanyak 30 responden petani kubis. Terdiri dari 25 responden pria dan 5 responden wanita. Umur responden berkisar 29 sampai 60 tahun, dengan demikian dapat dikatakan bahwa seluruh responden dalam penelitian ini berusia produktif. Sebagaimana Anjayani dan Haryanto, 2009) yang menyatakan bahwa penduduk yang 
berumur 15 sampai 59 tahun penduduk usia produktif. Sebab usia 29 sampai dengan 60 tahun responden dianggap cenderung lebih mudah dalam menerima hal-hal baru yang dapat membawa pengaruh baik terhadap pendapatan usaha tani mereka. Umur dapat mempengaruhi sikap petani terhadap pengambilan keputusan dalam usahatani (Brown dkk., 2019; Burton, 2006; EdwardsJones, 2006; Hardana dkk., 2019; May dkk., 2019; Mukhopadhyay dkk., 2019). Kemampuan kerja petani dalam melaksanakan kegiatan usahatani diketahui dari umur. Petani yang bekerja dalam usia produktif akan lebih baik dan maksimal dibandingkan usia non-produktif. Selain itu, umur juga dapat dijadikan sebagai tolak ukur dalam melihat aktivitas petani dalam berusahatani (Hasyim, 2006). Menurut Arifin dkk. (2020), usia responden dapat dikaitkan dengan kemampuan fisik responden untuk menjalankan pertanian.

Pendidikan responden bervariasi antara responden yang satu dan responden lainnya mulai dari yang berpendidikan SD hingga pendidikan tinggi. Sebagian besar responden Iulusan Sekolah Dasar yaitu sebanyak 36.66\%, Iulusan Sekolah Lanjutan Tingkat Pertama sebanyak 30 \%, lulusan Sekolah Menengah Pertama sebanyak 20\%, dan lulusan Sekolah Tinggi sebanyak 13.3\%. Dalam kemampuan cepat tidaknya dalam mengadopsi teknologi dapat dipengaruhi oleh tinggi rendahnya pendidikan. Dalam hal ini dapat dijelaskan bahwa petani yang memiliki tingkat pendidikan rendah dapat berakibat lambat dan sulit dalam menyerap kemajuan teknologi dan mengadopsi hal-hal baru. Menurut Lubis (2000) tingkat pengetahuan serta wawasan yang dimiliki petani dalam menerapkan teknologi dan inovasi untuk meningkatkan usahataninya dipengaruhi oleh tinggi rendahnya tingkat pendidikan yang dimiliki seorang petani itu sendiri.

Salah satu yang dapat mempengaruhi seseorang dalam pengambilan keputusan adalah pengalaman yang telah dimiliki, hal ini identik dengan penelitian terdahulu bahwa pengalaman petani berperan penting (Bramley \& Ouzman, 2019; Kernecker dkk., 2020; Wrigley-Asante dkk., 2019). Berdasarkan jangka waktu dalam bertani kubis berkisar antara 8 sampai 20 tahun. Petani Kubis di Desa Beji sudah berpengalaman kurang $\leq 10$ tahun yaitu 11 orang $(3,66 \%)$ dan yang berpengalaman lebih $>10$ tahun yaitu 19 orang (63.33\%).

\section{Analisis usaha tani}

\section{Usaha tani}

Keuntungan secara terus menerus dan bersifat komersial merupakan bagian dari berusahatani (Dewi dkk., 2012). Pengertian Ilmu usahatani termasuk mempelajari tentang cara mengalokasikan sumberdaya yang dimiliki secara efektif dan efisien untuk dengan tujuan memperoleh keuntungan yang tinggi (Suratiyah, 2016). Salah satu faktor yang dapat mempengaruhi usahatani adalah faktor sosial 
ekonomi petani meliputi umur, tingkat aturan yang dapat digunakan untuk mengatur pendidikan, pengalaman usahatani, jumlah usahatani dengan baik sehingga dapat tanggungan keluarga dan milik lahan memperoleh pendapatan yang tinggi. Untuk (Tambunan, 2003). Prasetya (2010) dapat mengetahui analisis penerimaan, biaya menyatakan bahwa usahatani merupakan dan pendapatan usaha tani kubis adalah suatu ilmu yang mempelajari tentang aturan- sebagai berikut:

Tabel 3. Biaya, penerimaan dan pendapatan petani kubis dalam satu kali panen

\begin{tabular}{lr}
\hline \multicolumn{2}{c}{ Varian } \\
\hline Produksi rata-rata /Kg & Rp/Ha \\
Harga (Rp/Kg) & 7125 \\
Total Penerimaan & $\mathbf{5 3 . 4 7 3 . 5 0 0}$ \\
Biaya Tetap: & \\
Sewa Lahan & 1.200 .00 \\
Pajak & 750.000 \\
Penyusutan alat & 1.060 .000 \\
Total Biaya Tetap & $\mathbf{3 . 0 1 0 . 0 0 0}$ \\
Biaya Variabel: & \\
Tenaga kerja & \\
Benih & 2.950 .200 \\
Pupuk kandang & 675.250 \\
Pupuk urea & 1.360 .000 \\
Pupuk Za & 825.500 \\
Pupuk Sp326 & 425.500 \\
Pupuk ponska & 370.255 \\
Pestisida & 1.250 .220 \\
Pengangkutan & 1.800 .100 \\
Total Biaya Variabel & 2.150 .000 \\
Total Biaya & $\mathbf{1 1 . 8 0 7 . 0 2 5}$ \\
Pendapatan & $\mathbf{1 4 . 8 1 7 . 0 2 5}$ \\
Nilai R/C & $\mathbf{1 4 . 8 1 7 . 0 2 5}$ \\
Sumber: Analsis, & $\mathbf{2 . 6 1}$ \\
\hline
\end{tabular}

Sumber: Analisis, 2020

Berdasarkan tabel 3 di atas dapat membusuk akibat cuaca yang tidak menentu, diketahui bahwa penerimaan petani kubis serangan hama dan pemupukan yang kurang dalam satu kali musim tanam sebesar Rp. tepat sehingga mengakibatkan produktivitas 53.473.500,00. Penerimaan yang di dapat kubis menurun. Dengan penurunan petani kubis kali ini lumayan cukup besar, produktivitas akan menyebabkan kenaikan karena harga kubis terus mengalami kenaikan harga kubis, karena permintaan kubis yang hampir setiap hari di sejumlah pasar tradisional tinggi dan produksi kubis menurun.

Kota Batu dan sekitarnya. Saat ini harga kubis Proses pengelompokan secara sistematis yaitu naik hingga kisaran Rp. 7.500,00/Kg. Hal seluruh elemen dalam golongan tertentu yang ini dikarenakan banyak kubis petani yang lebih ringkas agar dapat memberikan informasi 
yang lebih baik disebut pengelolaan biaya (Supriyono, 2002). Biaya yang relatif tetap jumlahnya dan terus dikeluarkan meskipun jumlah produksi yang didapatkan tinggi maupun rendah disebut dengan biaya tetap. Sehingga besarnya biaya tetap tidak tergantung pada besar kecilnya produksi yang didapatkan. Berdasarkan tabel di atas besarnya biaya tetap ini meliputi sewa lahan sebesar Rp. 1.200.000,00/ha; pajak sebesar Rp. 750.000,00/ha dan penyusutan sebesar Rp. 1.060.000,00/ha. Dengan demikian total rata-rata biaya tetap yang dikeluarkan petani responden adalah $\mathrm{Rp}$. 3.010.000,00/ha.

Biaya variabel adalah biaya yang terus dikeluarkan walaupun jumlah produksi yang dihasilkan rendah maupun tinggi yang memiliki ciri biaya persatuan yang dipengaruhi oleh perubahan volume kegiatan. Berdasarkan tabel di atas biaya variabel meliputi biaya tenaga kerja sebesar Rp. 2.950.200,00/ha, biaya benih sebesar Rp. 675.250,00/ha, biaya pupuk kandang sebesar Rp. 1.360.000,00/ha, biaya pupuk urea sebesar Rp. $825.500,00 /$ ha, biaya pupuk Za sebesar Rp. 425.000,00/ha, biaya pupuk Sp326 sebesar Rp. 370,225,00/ha, biaya pupuk ponska sebesar Rp. 1.250.220,00/ha, biaya pestisida sebesar Rp. 1.800.100,00/ha dan biaya pengangkutan sebesar Rp. 2.150.000,00/ha. Petani kubis mengeluarkan biaya variabel sebesar Rp. 11.807.025,00/ha dengan total biaya sebesar Rp. 14.817.025,00/ha.
Soekartawi (2016) menyatakan bahwa keuntungan usahatani bisa diukur menggunakan ketetapan besarnya pendapatan yang dapat diterima oleh petani. Menurut Malinga dkk. (2015) untuk meningkatkan pendapatan dan menyediakan lapangan kerja yang menguntungkan, diversifikasi dari tanaman biji-bijian ke tanaman bernilai tinggi seperti sayuran tampaknya menjadi strategi penting untuk pertumbuhan pertanian untuk negara berkembang. Rata-rata pendapatan petani kubis sebesar Rp. 38.656.475,00. Hal tersebut menunjukkan, nilai yang di dapat petani kubis cukup besar. Apabila dalam mengelola usahatani tersebut dilakukan dengan cara yang lebih intensif serta efisien, petani kubis dapat memperoleh penerimaan yang tinggi, sehingga meningkatkan pendapatan. Untung ruginya dalam berusaha tani kubis dapat dilihat dari nilai rata-rata $\mathrm{R} / \mathrm{C}$ yang diperoleh, dalam hal ini sebesar 2,61, dengan demikian usahatani kubis ini layak untuk diusahakan. Hasil penelitian ini didukung oleh hasil penelitian (Supawadee, 2013) yang menyatakan bahwa usahatani yang dijalankan sangat menguntungkan dengan perolehan $\mathrm{R} / \mathrm{C}$ sebesar 3,4. Hal ini dikarenakan selain adanya dukungan alam, kesuburan tanah, juga karena para petani di Laos sudah terampil dalam bertani. 


\section{KESIMPULAN}

Total penerimaan petani kubis dalam satu kali panen diperoleh sebesar Rp. 53.473.500,00. Total pendapatan yang diperoleh petani kubis adalah $\mathrm{Rp}$. 38.656.475,00, -. Usahatani Kubis di Desa Beji, layak untuk diusahakan karena memiliki nilai R/C 2,61 dapat diartikan bahwa setiap pengeluaran Rp. 100,- maka penghasilan petani meningkat sebesar Rp. 261,--

\section{DAFTAR PUSTAKA}

Alamgir, A. (2018). Vitamins, nutraceuticals, food additives, enzymes, anesthetic aids, and cosmetics. In Therapeutic Use of Medicinal Plants and their Extracts: Volume 2 (pp. 407-534). Springer.

Anjayani, E., \& Haryanto, T. (2009). Geografi untuk kelas X SMA/MA. Jakarta: PT. Cempaka Putih.

Anunciação, D. S., Leao, D. J., de Jesus, R. M., \& Ferreira, S. L. (2011). Use of multivariate analysis techniques for evaluation of analytical data-Determination of the mineral composition of cabbage (Brassica oleracea). Food Analytical Methods, 4(3), 286-292. https://doi.org/10.1007/ s12161-010-9172-2.

Arifin, Z., Prasetyo, E., \& Setiawan, B. M. (2020). Analysis of technical and economic efficiency of the use of production faktors at cabbage farming in getasan district semarang regency. http://www.doarj.org /ijhrss/wp-content/uploads/2020/IJHRSS /01/1.pdf.

Aschemann-Witzel, J., Ares, G., Thøgersen, J., \& Monteleone, E. (2019). A sense of sustainability? -How sensory consumer science can contribute to sustainable development of the food sector. Trends in Food Science \& Technology, 90, 180-186.

Ashari, S. (1995). Hortikultura, Aspek Budidaya. Jakarta.
Bramley, R., \& Ouzman, J. (2019). Farmer attitudes to the use of sensors and automation in fertilizer decision-making: Nitrogen fertilization in the Australian grains sector. Precision Agriculture, 20(1), 157-175.

Brown, P., Daigneault, A., \& Dawson, J. (2019). Age, values, farming objectives, past management decisions, and future intentions in New Zealand agriculture. Journal of Environmental Management, 231, 110-120.

Burton, R. J. (2006). An alternative to farmer age as an indicator of life-cycle stage: The case for a farm family age index. Journal of Rural Studies, 22(4), 485-492.

Cahyono, I. B. (2002). Wortel, teknik budi daya dan analisis usaha tani. Kanisius.

Dewi, I. G. A. C., Suamba, I. K., \& Ambarawati, I. G. (2012). Analisis Efisiensi Usahatani Padi Sawah (Studi Kasus di Subak Pacung Babakan, Kecamatan Mengwi, Kabupaten Badung). Jurnal Agribisnis Dan Agrowisata (Journal of Agribusiness and Agritourism). https://ojs.unud.ac.id/ index.php/JAA/article/view/1122.

Edwards-Jones, G. (2006). Modelling farmer decision-making: Concepts, progress and challenges. Animal Science, 82(6), 783790.

Faizal, N. H. (2007). Ekonomi manajerial. PT Raja Grafindo Persada. Jakarta.

Fitriani (2012). Untung berlipat dengan budidaya tomat di berbagai media tanam. Pustaka Baru Press.

Hardana, A. E., Pratiwi, D. E., \& Ambayoen, M. A. (2019, May). Analisis faktor-faktor yang mempengaruhi keputusan petani hortikultura dalam mengakses pembiayaan mikro di Jawa Timur. In Prosiding Seminar Nasional Lingkungan Lahan Basah (Vol. 4, No. 1, pp. 38-44). http://snllb.ulm.ac.id/prosiding/index.ph p/snllb-lit/article/view/156.

Hasyim, H. (2006). Analisis Hubungan Karakteristik Petani Kopi Terhadap Pendapatan (Studi Kasus: Desa Dolok Saribu Kecamatan Paguran Kabupaten 
Tapanuli Utara) [Thesis]. Universitas Sumatra Utara

Kernecker, M., Knierim, A., Wurbs, A., Kraus, T., \& Borges, F. (2020). Experience versus expectation: Farmers' perceptions of smart farming technologies for cropping systems across Europe. Precision Agriculture, 21(1), 34-50.

Lubis, S. (2000). Adopsi Teknologi dan FaktorFaktor yang mempengaruhinya. USU. Press Medan.

Malinga, N., Masuku, M., \& Raufu, M. (2015). Comparative analysis of technical efficiencies of smallholder vegetable farmers with and without credit access in swazil and the case of the Hhohho region. International Journal of Sustainable Agricultural Research, 2(4), 133-145. https://doi.org/10.18488/journal.70/201

5.2.4/70.4.133.145.

May, D., Arancibia, S., Behrendt, K., \& Adams, J. (2019). Preventing young farmers from leaving the farm: Investigating the effectiveness of the young farmer payment using a behavioural approach. Land Use Policy, 82(1), 317-327.

Movilla-Pateiro, L., Mahou-Lago, X., Doval, M., \& Simal-Gandara, J. (2020). Toward a sustainable metric and indicators for the goal of sustainability in agricultural and food production. Critical Reviews in Food Science and Nutrition, 1-22.

Mukhopadhyay, P., Sinha, M., \& Sengupta, P. P. (2019). Determinants of farmers' decision-making to accept crop insurance: A multinomial logit model approach. In Soft Computing in Data Analytics (pp. 267-275). Springer.

Narimawati, U. (2008). Metodologi penelitian kualitatif dan kuantitatif, teori dan aplikasi. Bandung: Agung Media.

Nemeth, N., Rudnak, I., Ymeri, P., \& Fogarassy, C. (2019). The role of cultural faktors in sustainable food consumption-an investigation of the consumption habits among international students in Hungary. Sustainability, 11(11), 3052.

Patty, J. A. (2018). Peran tanaman aromatik dalam menekan perkembangan hama spodoptera litura pada tanaman kubis. Agrologia, 1(2), 126-133.

Prasetya. (2010). Analisis efisiensi ekonomi penggunaan faktor-faktor produksi pada usahatani melon di Kabupaten Grobogan [Tugas Akhir]. Universitas Sebelas Maret.

Sheng, Y., \& Song, L. (2019). Agricultural production and food consumption in China: A long-term projection. China Economic Review, 53(1), 15-29.

Soekartawi. (2016). Analisis usahatani. Jakarta: Universitan Indonesia (UIPress),

Soekartawi (2007). Teori ekonomi produksi. Jakarta: Rajawali Press.

Sudrajat, (200). Dasar-dasar penelitian ilmiah, Bandung: Pustaka Setia

Sun, C., Wang, L., Hu, D., Riquicho, A. R. M., Liu, T., Hou, X., \& Li, Y. (2014). Proteomic analysis of non-heading Chinese cabbage infected with Hyaloperonospora parasitica. Journal of Proteomics, 98, 1530.

Supawadee, K. (2013). Benefits and efficiency of cabbage production of lao farmers under thai-laos contract farming. ChinaUSA Business Review, 12(7). https://doi.org/10.17265/15371514/2013.07.002.

Suprioyo (2002). Macam-macam biaya usahatani. Penebar Swadaya. Bandung.

Suratiyah. (2016). Ilmu usahatani. Penebar Swadaya. Jakarta.

Tambunan, T. (2003). Perkembangan sektor pertanian di Indonesia. Ghalia Indonesia.

Wrigley-Asante, C., Owusu, K., Egyir, I. S., and Owiyo, T. M. (2019). Gender dimensions of climate change adaptation practices: The experiences of smallholder crop farmers in the transition zone of Ghana. African Geographical Review, 38(2), 126139. 